\title{
Lung function 22-35 years after treatment of idiopathic spontaneous pneumothorax with talc poudrage or simple drainage
}

\author{
PETER LANGE, JANN MORTENSEN, STEFFEN GROTH \\ From Medical Department $P$ and Chest Clinic and the Department of Clinical Physiology and Nuclear \\ Medicine, Bispebjerg Hospital, Copenhagen, Denmark
}

\begin{abstract}
The long term effects on lung function of treatment of idiopathic spontaneous pneumothorax by talc poudrage or simple chest drainage were assessed in 114 patients. Subjects were studied 22-35 years after their first pneumothorax with measurement of static and dynamic lung volumes. Eighty patients had been treated with talc pleurodesis and 34 with simple pleural drainage. At the follow up examination 17 had died from what appear to be unrelated causes and two had emigrated. Of the remainder, 75 participated fully in the study, 14 completed a postal questionnaire, and six failed to respond. The group treated with talc poudrage showed a mild restrictive impairment of lung function with a mean total lung capacity (TLC) of $89 \%$ predicted. In subjects treated with simple drainage mean TLC was $96 \%$ predicted. One subject treated with talc poudrage had extensive pleural calcification and a substantial reduction in lung function (TLC $58 \%$ predicted) with some evidence of lung fibrosis. None of the subjects had developed a mesothelioma. We conclude that, although talc poudrage may cause a mild restrictive impairment of lung function and pleural thickening on the chest radiograph, the long term outlook is good.
\end{abstract}

\section{Introduction}

Idiopathic spontaneous pneumothorax is a relatively rare condition with an incidence of about four or five cases/100 000 people a year. ${ }^{12}$ It occurs in previously healthy young adults and is caused by a rupture of a small, often apically located, pulmonary bleb. ${ }^{3}$ The male to female ratio is about $6: 1$.

There has been some interest in the effect of pneumothorax on lung function at the time of the pneumothorax ${ }^{4}$ or shortly after resolution..$^{6-9}$ There are few reports, however, on the long term effect of spontaneous pneumothorax on pulmonary function $^{2} 10$ and insufficient patients have been studied to assess the impact of the initial treatment.

We studied lung function in subjects who were still alive 22 years or more after a first episode of idiopathic spontaneous pneumothorax. Results were related to the initial treatment, which was either talc poudrage or simple drainage. Particular interest was directed to

Address for reprint requests: Dr Peter Lange, Medical Department P/ Chest Clinic, Bispebjerg Hospital, Bispebjerg Bakke 23, DK-2400 Copenhagen NV, Denmark.

Accepted 14 April 1988 possible late effects of talc poudrage, including malignancy.

\section{Methods}

\section{PATIENTS}

The study population consisted of 114 consecutive patients treated at the chest clinics at Øresundshospitalet and Bispebjerg Hospital, Copenhagen, for their first episode of idiopathic spontaneous pneumothorax during 1951-63. The diagnosis was based on the presentation of a spontaneous pneumothorax in a patient with no prior history of pulmonary disease.

Ninety nine patients were men and 15 women. At the time of the first pneumothorax $99(87 \%)$ of the subjects were under 41 years of age. The initial treatment was talc poudrage followed by drainage via an intercostal tube ${ }^{11}$ in 60 patients and simple drainage via an intercostal tube in 54 patients. In the latter group 20 patients $(37 \%)$ had an ipsilateral relapse and this was treated with talc poudrage in all instances. Among the 80 patients treated with talc poudrage for their first episode or for a relapse there was relapse at the side of treatment in two patients $(2.5 \%)$.

The 80 patients treated with talc poudrage either for 
the first episode of pneumothorax (60 patients) or for the recurrence of pneumothorax (20 patients) have been designated group 1 and the 34 patients treated with simple drainage only group 2 .

In autumn 1985 all subjects were traced through the population register. Seventeen had died and two had emigrated. The remaining 95 were invited to undergo an interview and physical examination. Seventy five consented. Of the remainder, 14 filled in a questionnaire but did not wish to attend the examination centre, mainly for reasons of geographical distance; six failed to respond but we were able to ascertain that they had not been in contact with a local chest clinic recently.

\section{PULMONARY INVESTIGATION}

Forced expiratory volume in one second $\left(\mathrm{FEV}_{1}\right)$ and vital capacity (VC) were measured with a Pulmonet III (Gould) spirometer, the best of at least three recordings being used. Total lung capacity (TLC) and residual volume (RV) were measured by a closed circuit helium equilibrium method. The examinations were carried out according to the recommendations of the European Steel and Coal Union. ${ }^{12}$ The results were converted to BTPS and related to predicted values. ${ }^{13}$ Chest radiographs in two projections were obtained. Medical details recorded after the first episode of spontaneous pneumothorax were noted.

\section{ANALYSIS OF RESULTS}

Results were analysed by Student's $t$ test for unpaired data and the $\chi^{2}$ test.

\section{Results}

Seventeen of the 114 subjects had died. Three had died from lung cancer but none of the remaining deaths was due to respiratory failure or mesothelioma.

Mean values for TLC, VC and FEV, were lower than predicted (table), but the impairment was slight $\stackrel{5}{?}$ and in most subjects values were within the normal ? range. Subjects in group 1 (talc poudrage) had significantly lower TLC values than group 2 .

Of the 75 patients who had a chest radiograph, $51 \stackrel{\AA}{\circledR}$ showed pleural thickening. There was no significant is difference in the incidence of pleural changes on the $\vec{\circ}$ chest radiograph between group $1(76 \%)$ and group 2. $(55 \%)$. Subjects with pleural thickening had sig- $\vec{\omega}$ nificantly lower values for TLC (89\% predicted) and $\mathrm{O}$ VC $(80 \%$ predicted) than those without pleural thick- $\vec{x}$ ening (TLC $98 \%$ predicted and VC $88 \%$ predicted). The pleural changes were usually small but two subjects treated with talc poudrage had more extensive if pleural thickening with calcification. One of the two subjects, a woman, was the only subject with severe 을 restrictive impairment of lung function (TLC $58 \%-$ predicted, $\mathrm{FEV}_{1} / \mathrm{VC} 77 \%$ ). She had had three pneumothoraces (one on the left side and two on the right) and had been treated with talc pleurodesis on the $\vec{\varphi}$ left side and hypertonic glucose pleurodesis on $\infty$ the right, but both treatments had been complicated $\square$ by persistent pleural effusions requiring several pleurocenteses. Further investigations, including computed tomography of the thorax and measurement of transfer factor for carbon monoxide $(9.6 \mathrm{ml} / \mathrm{min} / \stackrel{\circ}{\mathbb{D}}$ mm Hg: $48 \%$ predicted) and pulmonary epithelial $\stackrel{\circ}{\Rightarrow}$ permeability to inhaled technetium- $99 \mathrm{~m}$ labelled $\overrightarrow{\overline{0}}$ DTPA $(3.9 \% / \mathrm{min}: 450 \%$ predicted) suggested that she also had a moderate degree of pulmonary fibrosis.

The mean TLC in subjects with recurrent pneumothorax was significantly lower $(88 \%$ predicted) than that in subjects with no recurrence $(95 \%$ predicted).

Fourteen subjects had airflow limitation $\left(\mathrm{FEV}_{1} / \stackrel{3}{3}\right.$

Mean (SD) lung function values

\begin{tabular}{|c|c|c|c|c|c|c|c|c|c|}
\hline & \multicolumn{3}{|l|}{$T L C$} & \multicolumn{3}{|l|}{$V C$} & \multicolumn{3}{|l|}{$F E V_{1}$} \\
\hline & Litres & $\%$ pred & $p$ & Litres & $\%$ pred & $p$ & Litres & $\%$ pred & $p$ \\
\hline $\begin{array}{l}\text { Total studied } \\
(\mathrm{n}=75)\end{array}$ & $\begin{array}{c}6.31 \\
(1.05)\end{array}$ & $\begin{array}{c}92 \\
(15)\end{array}$ & & $\begin{array}{c}3.64 \\
(0.81)\end{array}$ & $\begin{array}{c}83 \\
(15)\end{array}$ & & $\begin{array}{c}2 \cdot 58 \\
(0 \cdot 78)\end{array}$ & $\begin{array}{c}74 \\
(19)\end{array}$ & \\
\hline $\begin{array}{l}\text { Talc poudrage } \\
(n=46) \\
\text { No talc poudrage } \\
(n=29)\end{array}$ & $\begin{array}{c}6 \cdot 31 \\
(1 \cdot 20) \\
\\
6 \cdot 30 \\
(0 \cdot 77)\end{array}$ & $\begin{array}{c}89 \\
(15) \\
96 \\
(12)\end{array}$ & $<0.05$ & $\begin{array}{c}3.68 \\
(0.88) \\
\\
3.57 \\
(0.67)\end{array}$ & $\begin{array}{l}82 \\
(16) \\
\\
85 \\
(11 \cdot 5)\end{array}$ & NS & $\begin{array}{c}2.54 \\
(0.84) \\
\\
2.63 \\
(0.66)\end{array}$ & $\begin{array}{c}72 \\
(21) \\
78 \\
(15)\end{array}$ & NS \\
\hline $\begin{array}{l}\text { Pleural changes } \\
(n=51) \\
\text { No pleural changes } \\
(n=24)\end{array}$ & $\begin{array}{c}6 \cdot 14 \\
(0.94) \\
6.64 \\
(1 \cdot 18)\end{array}$ & $\begin{array}{l}89 \\
(13) \\
98 \\
(15)\end{array}$ & $<0.01$ & $\begin{array}{c}3.55 \\
(0.80) \\
\\
3.81 \\
(0.80)\end{array}$ & $\begin{array}{l}80 \\
(15) \\
88 \\
(13)\end{array}$ & $<0.025$ & $\begin{array}{c}2 \cdot 51 \\
(0 \cdot 77) \\
2 \cdot 70 \\
(0 \cdot 80)\end{array}$ & $\begin{array}{c}72 \\
(18) \\
78 \\
(20)\end{array}$ & NS \\
\hline
\end{tabular}


$\mathrm{VC} \leqslant 65 \%$ and $\mathrm{RV} / \mathrm{TLV} \geqslant 40 \%$ ), and in five this was severe $\left(\mathrm{FEV}_{1} \leqslant 50 \%\right.$ predicted). All but two were lifelong heavy smokers.

\section{Discussion}

This study shows that idiopathic spontaneous pneumothorax may be followed by a mild restrictive impairment of lung function. This restrictive pattern was associated with pleural thickening.

In a five to six year follow up of 58 subjects with spontaneous pneumothorax Hallgrimsson found that four of the eight subjects with restrictive impairment of lung function (TLC $\leqslant 80 \%$ predicted) had pleural adhesions. ${ }^{2}$ A similar association between pleural thickening and a restrictive impairment of lung function has been suggested in other studies of the short term changes after spontaneous pneumothorax ${ }^{78}$ and in studies of pleural adhesions and pleural thickening after artificial pneumothorax. ${ }^{14} 15$ It has been suggested that spontaneous pneumothorax may be an early sign of pulmonary emphysema, ${ }^{78}$ but our results do not support this hypothesis.

In our study subjects treated with talc poudrage had slightly more impairment of lung function than those treated with simple drainage. The restrictive changes did not, however, cause symptoms except in one subject. In this subject the impairment of lung function that followed talc poudrage was probably not due to pleural thickening alone, as there was some evidence of lung fibrosis in addition.

Asbestos pollution of the talc has been suggested as a risk factor for the development of mesothelioma. ${ }^{16}$ This was not seen in this study despite our observation time of 22-35 years. As the latent period between asbestos exposure and the development of mesothelioma has been longer than 40 years in some studies our work does not entirely exclude the possibility of asbestos pollution of the talc.

When the choice is made between the greater risk of relapse associated with simple drainage and the transitory discomfort and slightly greater restrictive impairment of lung function with talc poudrage, it is comforting to know that, regardless of the choice, the long term prognosis with regard to lung function is good.

This study was supported by grants from the National Union for the Fight against Tuberculosis and Lung Diseases.

\section{References}

1 Melton LJ, Hepper NGG, Offord KP. Incidence of spontaneous pneumothorax in Olmsted County, Minnesota: 1950 to 1974. Am Rev Respir Dis 1979;120: 1379-82.

2 Hallgrimsson JG. Spontaneous pneumothorax in Iceland with special reference to the idiopathic type: a clinical and epidemiological investigation. Scand $J$ Thorac Cardiovasc Surg 1978;21(suppl):9-85.

$3 \mathrm{Kjaergaard} \mathrm{H}$. Spontaneous pneumothorax in the apparently healthy. Acta Med Scand 1932;43(suppl): $1-159$.

4 Gilmartin JJ, Wright AJ, Gibson GJ. Effects of pneumothorax or pleural effusion on pulmonary function. Thorax 1985;40:60-5.

5 Anthonisen NR. Regional lung function in spontaneous pneumothorax. Am Rev Respir Dis 1977;115:873-6.

6 Heckscher TH, Andree Larsen O, Lassen NA. A clinical method for determination of regional lung function using intravenous injection of $\mathrm{Xe}^{133}$. Scand J Respir Dis 1966;62(suppl):31-9.

7 De Troyer A, Yernault JC, Rodenstein D, Englert M, De Coster A. Pulmonary function in patients with primary spontaneous pneumothorax. Bull Eur Physiopathol Respir 1978;14:31-9.

8 Williams $\mathrm{MH}$, Kane C. Pulmonary function in patients who have recovered from spontaneous pneumothorax. Dis Chest 1965;47:153-6.

9 Baronofsky ID, Warden HG, Kaufman JL, Whatley J, Hanner JM. Bilateral therapy for unilateral spontaneous pneumothorax. $J$ Thorac Surg 1957;34:310-9.

10 Fleetham JA, Forkert L, Clarke H, Anthonisen NR. Regional lung function in presence of pleural symphysis. Am Rev Respir Dis 1980;122:33-8.

11 Bethune N. Pleural poudrage-a new technique for the deliberate production of pleural adhesion as a preliminary to lobectomy. J Thorac Surg 1935;4:251-61.

12 Quanjer PH, ed. Standardised lung function testing. Report of working party of the European Community for Coal and Steel. Bull Eur Physiopathol Respir 1983;19(suppl 5):1-96.

13 Dirksen A, Groth S. Calculation of reference values for lung function tests. Bull Eur Physiopathol Respir 1986;22:231-7.

14 Patiala J, Karvonen MJ. Studies on pulmonary function after pneumothorax therapy. Acta Tuberc Scand 1954; 29:193-210.

15 Autio V. The reduction of respiratory function by parenchymal and pleural lesions. Acta Tuberc Scand 1959;37:112-25.

16 Research Committee of the British Thoracic Association and the Medical Research Council Pneumoconiosis Unit. The survey of the long-term effects of talc and kaolin pleurodesis. Br J Dis Chest 1979;73:285-8. 